\title{
Improvement of Shelf Life and Sensory Quality of Pears Using a Specialized Edible Coating
}

\author{
Virgilio Cruz, ${ }^{1}$ Romeo Rojas, ${ }^{2}$ Saúl Saucedo-Pompa, ${ }^{1}$ \\ Dolores G. Martínez, ${ }^{3}$ Antonio F. Aguilera-Carbó, ${ }^{3}$ Olga B. Alvarez, ${ }^{1}$ \\ Raúl Rodríguez, ${ }^{1}$ Judith Ruiz, ${ }^{1}$ and Cristóbal N. Aguilar ${ }^{1}$

\begin{abstract}
${ }^{1}$ Department of Food Research, School of Chemistry, Universidad Autónoma de Coahuila, 25280 Saltillo, COAH, Mexico
${ }^{2}$ School of Agrnonmy, Research Center and Development for Food Industries and CIDIA, Universidad Autónoma de Nuevo León, 66050 General Escobedo, NL, Mexico

${ }^{3}$ Group of Food Biotechnology, Universidad Autónoma Agraria Antonio Narro, Calzada Antonio Narro 1923, Colonia Buenavista, 25315 Saltillo, COAH, Mexico
\end{abstract}

Correspondence should be addressed to Cristóbal N. Aguilar; cristobal.aguilar@uadec.edu.mx

Received 12 January 2015; Revised 5 March 2015; Accepted 5 March 2015

Academic Editor: Leiqing Pan

Copyright (C) 2015 Virgilio Cruz et al. This is an open access article distributed under the Creative Commons Attribution License, which permits unrestricted use, distribution, and reproduction in any medium, provided the original work is properly cited.

\begin{abstract}
An edible coating functionalized with pomegranate polyphenols was designed. Different blends of candelilla wax, gum arabic, jojoba oil, and pomegranate polyphenols were formulated in order to improve the shelf life quality of pears (variety Bartlett), and all formulations were applied by immersion onto the fruit surface. Coated pears with and without polyphenols and uncoated pears (control) were stored under the same conditions. Fruits were analyzed to evaluate changes in their physicochemical, microbiological, and sensorial properties during 30 days of storage at room temperature. Coated pears coded as T13 (candelilla wax $3 \%$, gum arabic $4 \%$, jojoba oil $0.15 \%$, and pomegranate polyphenols $0.015 \%$ ) extended and improved their shelf life quality due to the minimization of the physic-chemical changes and sensorial properties. Therefore, the results indicated that the formulated edible coating has potential to extend the shelf life and maintain quality of pears. It was probed that coated pears were accepted for consumers as a good product. Edible coating application represents a good alternative to keep pears freshness for longer periods.
\end{abstract}

\section{Introduction}

Pears (Pyrus communis) are climacteric fruits whose ripening is regulated by ethylene, exhibiting a relatively short shelf life. During ripening of pears, some changes are observed in firmness, color, acidity, sugar content, and development of aroma [1]. The optimum quality for eating pears is characterized by a buttery texture, appropriate color change, characteristic flavor associated with the content of sugars, acids, and volatile compounds [2].

Mexico is the biggest producer of pears in the world; nevertheless, the producers of this country are facing problems in not achieving the integration of horticultural products to national and international markets with quality products. For this reason in the last years, growers and packers are developing orchard management techniques, packing and shipping practices in order to export their fruit and vegetable products [3].

Some recent studies have been reported to prolong the shelf life of pears using edible coatings that are used to improve the mechanical integrity or handling characteristics of the fruits, reporting the ability of this technological strategy to retard changes in moisture, oxygen, aromas, and solute transport $[4,5]$ and the function of edible coating can be improved by including additives such as antioxidants, antimicrobials, colorants, flavors, fortifying nutrients, and spices in film formulation [6]. Besides, incorporation of antioxidants agents into packaging materials has also become very popular since oxidation is a major problem affecting food quality [7]. The coating applied can serve as a carrier 
for bioactive compounds and/or antioxidants compounds in order to maintain high concentrations of preservatives on food surfaces [8].

Edible coatings can be obtained from different types of materials, but the most used ones are made of polysaccharides $[4,5]$; however, certain limitations or disadvantages have been found due to their hygroscopic nature, particularly those made of starch and pectin.

On the other hand, polyphenols are secondary metabolites produced by higher plants. These compounds play different roles in the plant physiology and have potential healthy properties on human organism like antioxidants and antiallergic, antimicrobial agents among others. The incorporation of the process of the addition of the bioactive molecules like polyphenols to the edible films formulation in edible films is an alternative to bring all of these benefits to human organism through the consumption of natural products as well as help to prolong quality and shelf life thereof [9].

Earlier, we report the high efficiency of candelilla waxbased edible coatings to improve the shelf life of fresh-cut fruits [3], avocado [9], apples [10], strawberries [11], and bell peppers [12]. During their preparation, these lipid edible coatings are emulsified to promote adequate homogenization of the components and additives of the system, ensuring uniformity in size and distribution of the particles at the dispersed phase, improving the barrier functionality against the mass transfer of the film formed [13].

The short shelf life of pears is one of the biggest problems to be solved in Mexico. In the present study, the effort was focused on the elaboration of edible coatings with different concentrations of natural compounds such as candelilla wax (Euphorbia antisyphilitica Zucc.), gum arabic, jojoba oil, and polyphenols from pomegranate husk to evaluate the effect on the physicochemical and sensorial quality of pears.

\section{Materials and Methods}

2.1. Raw Materials. A lot of fruits of "Bartllet" pears (Pyrus communis L.) harvested in February of 2010 were obtained from a local market in Saltillo, Mexico, $24 \mathrm{~h}$ before treatments application. Fruits selection criteria were homogeneous size, absence of skin damage, visible absence of microorganisms, physiological maturity, and intense green color. Then, pears were taken and sorted in complete random groups, washed with detergent, and disinfected with a solution of sodium hypochlorite $\left(0.2 \mathrm{~g} \mathrm{~L}^{-1}\right)$ for $5 \mathrm{~min}$; finally, the excess of water was removed at room temperature [14].

2.2. Coating Formulation and Application. For coating formulation (patents RN MX/a/2010/001117 and MX/a/2013/ 012468), the components were mixed according to the Table 1 by DIA (UAdeC) and jojoba oil was used as plasticizer. The components of edible coating were mixed in water following that reported by Saucedo-Pompa [15] and Ochoa-Reyes et al. [12]. Mixture was heated at $80^{\circ} \mathrm{C}$ and homogenized at $2500 \mathrm{rpm}$ in an industrial homogenizer (International Mod. LI-17V). 17 different formulations were prepared according to
TABLE 1: Treatments and edible coating components (-) negative control, (+) positive control, and (T) treatment.

\begin{tabular}{|c|c|c|c|c|}
\hline \multirow[b]{2}{*}{ Treatment } & \multicolumn{4}{|c|}{ Edible coating components (\%) } \\
\hline & $\begin{array}{c}\text { Candelilla } \\
\text { wax }\end{array}$ & $\begin{array}{c}\text { Gum } \\
\text { arabic }\end{array}$ & Jojoba oil & $\begin{array}{l}\text { Pomegranate } \\
\text { polyphenols }\end{array}$ \\
\hline $\mathrm{T} 1$ & 2 & 3 & 0.3 & 0.01 \\
\hline $\mathrm{T} 2$ & 1 & 2 & 0.15 & 0.005 \\
\hline T3 & 3 & 2 & 0.15 & 0.005 \\
\hline $\mathrm{T} 4$ & 1 & 4 & 0.15 & 0.005 \\
\hline T5 & 3 & 4 & 0.15 & 0.005 \\
\hline T6 & 1 & 2 & 0.45 & 0.005 \\
\hline T7 & 3 & 2 & 0.45 & 0.005 \\
\hline $\mathrm{T} 8$ & 1 & 4 & 0.45 & 0.005 \\
\hline T9 & 3 & 4 & 0.45 & 0.005 \\
\hline $\mathrm{T} 10$ & 1 & 2 & 0.15 & 0.015 \\
\hline T11 & 3 & 2 & 0.15 & 0.015 \\
\hline $\mathrm{T} 12$ & 1 & 4 & 0.15 & 0.015 \\
\hline T13 & 3 & 4 & 0.15 & 0.015 \\
\hline $\mathrm{T} 14$ & 1 & 2 & 0.45 & 0.015 \\
\hline T15 & 3 & 2 & 0.45 & 0.015 \\
\hline T16 & 1 & 4 & 0.45 & 0.015 \\
\hline T17 & 3 & 4 & 0.45 & 0.015 \\
\hline $\mathrm{T}(-)$ & 0 & 0 & 0 & 0 \\
\hline $\mathrm{T}(+)$ & 2 & 3 & 0.3 & 0 \\
\hline
\end{tabular}

Table 1. Two controls were included, a negative control (fruits without edible coating, SC) and positive control (fruits with edible coating and without polyphenols, $\mathrm{BCO}$ ). Fruits were coated ( $2 \mathrm{~s}$ ) by immersion into coating solutions (Table 2) and then were put under an air flux until the solidification of edible coating (density $0.86 \mathrm{~g} \mathrm{~mL}^{-1}$ ). This process was repeated one more time according to that reported by Saucedo-Pompa et al. [3]. After coating, fruits were stored at room temperature for a period of 4 weeks $\left(23^{\circ} \mathrm{C} ; 70-75 \% \mathrm{RH}\right)$.

2.3. Shelf Life Assays. During the storage period, 4 parameters were monitored to measure pears shelf life with sampling every 7 days. Pears weight loss was gravimetrically measured with an analytical balance (Ohaus mode E-02130, Pine Brook, NJ). Appearance changes were photographically recorded with a digital camera (SONY Cyber-Shot with 14.1 megapixels with $4 \mathrm{x}$ zoom). All photographs were taken at the same angle and distance. Firmness of pears was measured with Humboldt Universal Penetrometer (Model H-1200, Chicago, IL) by measuring penetration $(\mathrm{mm})$. The $\mathrm{pH}$ values were obtained using a pH meter (Orion model -420, Boston, MA) using method reported by Saucedo-Pompa et al. [3]. Finally, parameters were weighted (selection index) according to their importance to obtain the best edible coating to preserve pears.

2.4. Sensory Evaluation. At the end of storage (4 weeks), sensorial differences among selected treatments were evaluated using a preference sensory test. 13 untrained judges evaluated 
TABLE 2: Preference results for each treatment of pears.

\begin{tabular}{lcccccccc}
\hline Attribute & T4 & T5 & T8 & T9 & T12 & T13 & Commercial & Total \\
\hline Appearance & $0.040^{\mathrm{b}}$ & 0.00 & 0.00 & $0.01^{\mathrm{b}}$ & $0.40^{\mathrm{b}}$ & $0.40^{\mathrm{b}}$ & $20.27^{\mathrm{a}}$ & $21.47^{\mathrm{a}}$ \\
Odor & $0.00^{\mathrm{b}}$ & $0.01^{\mathrm{b}}$ & $0.70^{\mathrm{b}}$ & $0.01^{\mathrm{b}}$ & $0.01^{\mathrm{b}}$ & 0.00 & $0.40^{\mathrm{b}}$ & $1.83^{\mathrm{b}}$ \\
Taste & $0.01^{\mathrm{b}}$ & $0.70^{\mathrm{b}}$ & $0.40^{\mathrm{b}}$ & $0.40^{\mathrm{b}}$ & $0.40^{\mathrm{b}}$ & $0.01^{\mathrm{b}}$ & $0.40^{\mathrm{b}}$ & $4.76^{\mathrm{b}}$ \\
Texture & $0.70^{\mathrm{b}}$ & $0.40^{\mathrm{b}}$ & $0.40^{\mathrm{b}}$ & $0.40^{\mathrm{b}}$ & $0.40^{\mathrm{b}}$ & $0.70^{\mathrm{b}}$ & $5.30^{\mathrm{b}}$ & $7.99^{\mathrm{b}}$ \\
\hline
\end{tabular}

Same small letters are not significantly different from each other $(P>0.05)$.

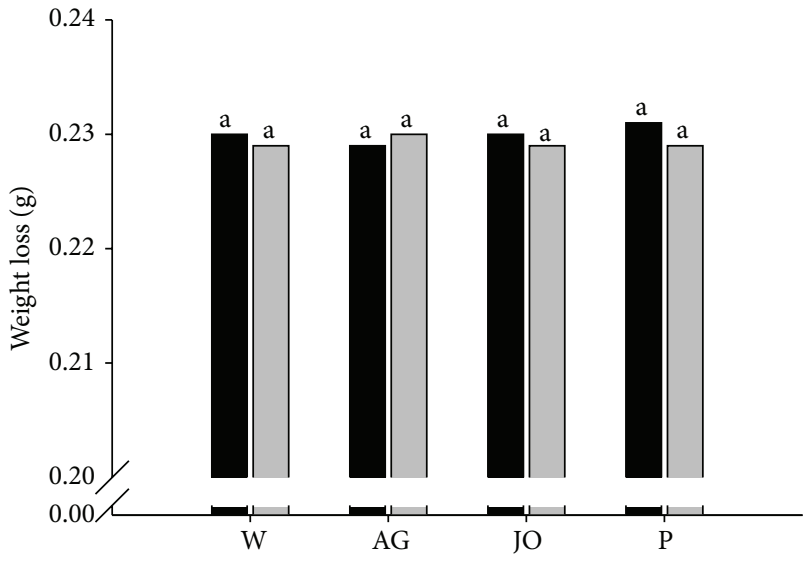

FIGURE 1: Weight loss: high (black) and low (gray). Same small letters are not significantly different from each other $(P>0.05)$.

appearance, odor, flavor, texture, and overall acceptance. For each judge, 7 samples corresponding to the treatments 4 , $5,8,9,12$, and 13 (selected from the selection index) and control (commercial fruit, fresh and without treatment) were evaluated. Each sample was identified with three digits; the judges were asked to rank the samples according to their preferences, the best appearance, odor, flavor, texture, and overall acceptance of the fruit.

2.5. Statistical Analysis. Data of edible coatings were analyzed using a complete randomized factorial arrangement $3^{2}$ design, with three replications. ANOVA and a Tukey test (HSD), $P<0.05$ for means comparison, were used to analyze the results using the statistical package SAS 9.0. For the analysis of the sensory test, data were analyzed using $\chi^{2}$ test. To establish significant difference, a significant level of $P<0.05$ was applied.

\section{Results and Discussion}

\subsection{Shelf Life}

3.1.1. Weight Loss. Weight loss value increases constantly $(P<0.05)$ during the evaluation period in all treatments (Figure 1). However, weight losses present no significant difference when different concentrations of components for all samples were applied. It can also be seen that the pears with the T13 treatment lost lesser weight than those with the control treatment, which showed the highest loss. This is

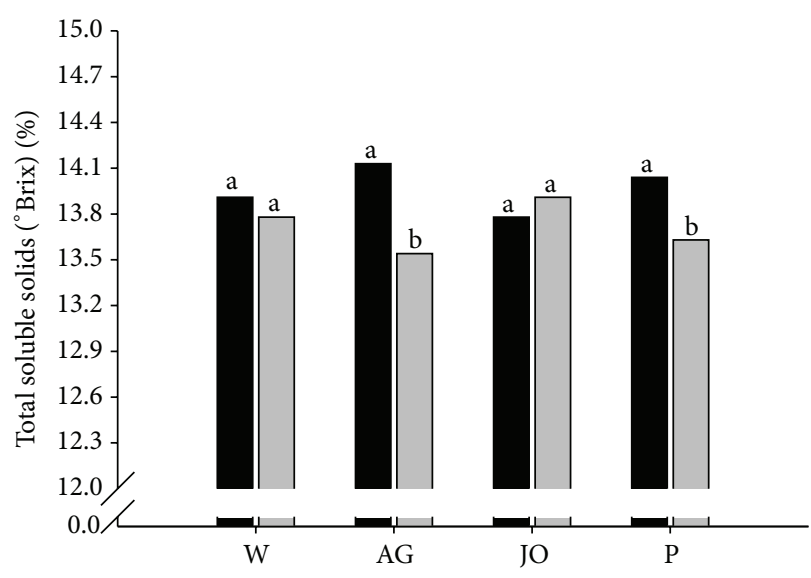

Figure 2: Total soluble solids ( ${ }^{\circ}$ Brix): (W) wax, (AG) gum arabic, (JO) jojoba oil, and (P) polyphenols. High (black) and low (gray). Same small letters are not significantly different from each other $(P>0.05)$.

attributed to the reduction of open area of the solids network, which restricted the transport of water vapor from the inside [16]. The use of $\mathrm{PPH}$ as an additive into the edible coatings led to decreased moisture loss of fruits. The reduction in weight loss is very important so fruits keep desirable to the consumers and the use of edible coatings is an excellent tool to control the weight reduction [14].

Several authors report that the use of lipid-based coating [17] retards moisture loss in apples [3, 10, 18], avocado [3, 9], papaya [19], strawberries [11], Persian limes [20], and mangoes [21] at room temperature. This is due to the barrier formed around the fruit [22], diminishing the concentration of $\mathrm{O}_{2}$ and increasing the $\mathrm{CO}_{2}$ in the fruit, that reduced the number of pores by which the water steam and the other gases are exchanged $[23,24]$.

With a selection index (Figure 6), it was possible to determine which treatment showed the best parameters values to preserve the fruits (better appearance, less weight loss, loss of firmness, and $\mathrm{pH}$ changing), resulting in the treatment T13, containing higher concentrations of the components, and resulting in the best formulation to improve the quality and prolong shelf life of pears.

3.1.2. Total Soluble Solids. Figure 2 shows changes in total soluble solids (TSS). The results $(P<0.05)$ indicate that using higher concentrations of candelilla wax (Euphorbia antisyphilitica Zucc.), gum arabic, and polyphenols from pomegranate husk and lower concentration of jojoba oil 


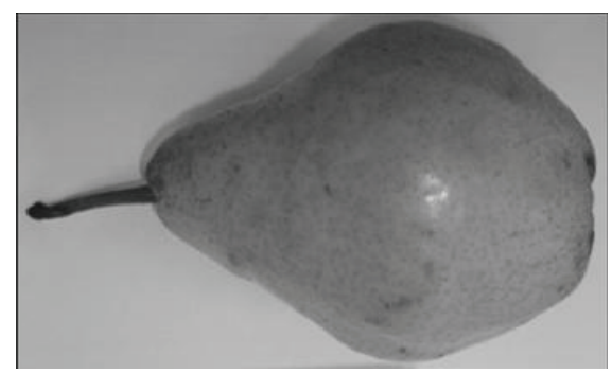

(a)

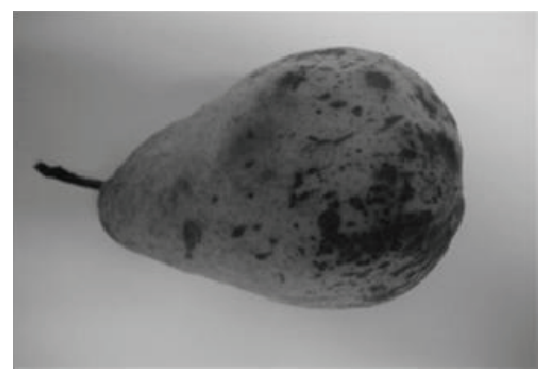

(b)

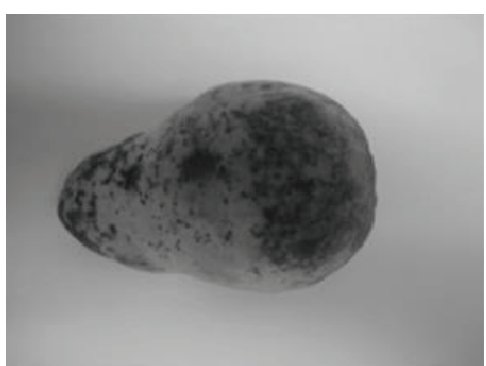

(c)

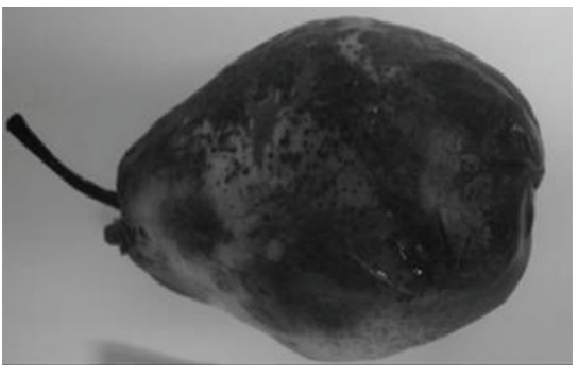

(d)

Figure 3: Visual appearance of pears with different treatments. T13 (a), T1 (positive control) (b), white (c), and negative control (d). Same small letters are not significantly different from each other $(P>0.05)$.

kept high TSS content, compared to treatments with lower concentrations of those compounds which is related to the acceleration of ripening of control fruits. This phenomenon can be explained due to the soluble solids and organic acids of fruit are substrates that are consumed by respiration during storage $[25,26]$.

3.1.3. Appearance Changes. All fruits presented changes in their external appearance, but the pears with T13 suffered a minor change compared with the other treatments (Figure 3). Also, positive controls suffered less damage than negative controls. The use of edible coatings considerably reduces apparent changes in fruits like papaya [14], apples [3, 10, 27], strawberries [11], and pears [28-31]. These changes can be due to the modified atmosphere created in the domestic fruit, with high levels of $\mathrm{CO}_{2}$ and low levels of $\mathrm{O}_{2}$, retarding the maturation processes $[14,20]$. Also, the benefits of using polyphenols like ellagic acid with candelilla wax as edible film have been clearly evidenced by Saucedo-Pompa et al. [3] that they demonstrated that these coatings improve the color and texture of fruits.

3.1.4. Firmness. Losses in the texture and consequent drop in consumer acceptability are the most noticeable changes occurring in pears during the prolonged storage in controlled atmosphere [32]. Our results obtained can be observed in Figure 4, in which it is possible to see that high concentrations of the components keep at the minimum this parameter. Also, the coated pears $(P<0.05)$ maintained initial firmness values. However, negative controls were severely affected compared to those coated with antioxidants adding. These results are similar to other authors to preserve pears from different varieties like "Flor de Invierno" [28], "Huanghua" [29, 30],

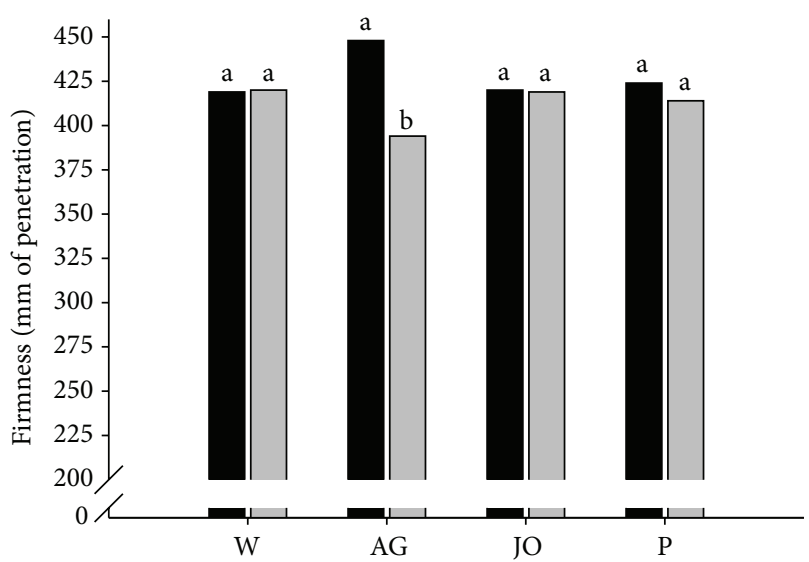

FIGURE 4: Loss of firmness: high (black) and low (gray). Same small letters are not significantly different from each other $(P>0.05)$.

"d'Anjou" [31], and other fruits and vegetables as tomatoes [33], apples [3, 11], and Japanese loquat [19].

This phenomenon can be explained by previous research that indicated the consequence of disassembly of primary cell wall and middle lamella structures of fruit flesh could contribute to changes in fruit texture during storage [34]. Firmness during ripening in climacteric fruit, such as pears, is generally attributed to degradation of the cell wall and loss of turgor pressure in the cells reduced by water loss [3537]. The data, mainly T13, indicated that coating treatments maintain firmness. This phenomenon may be due to the inhibition of water loss and the activities of pectin-degrading enzymes closely related to fruit softening by reducing the rate of metabolic processes during senescence $[38,39]$. 


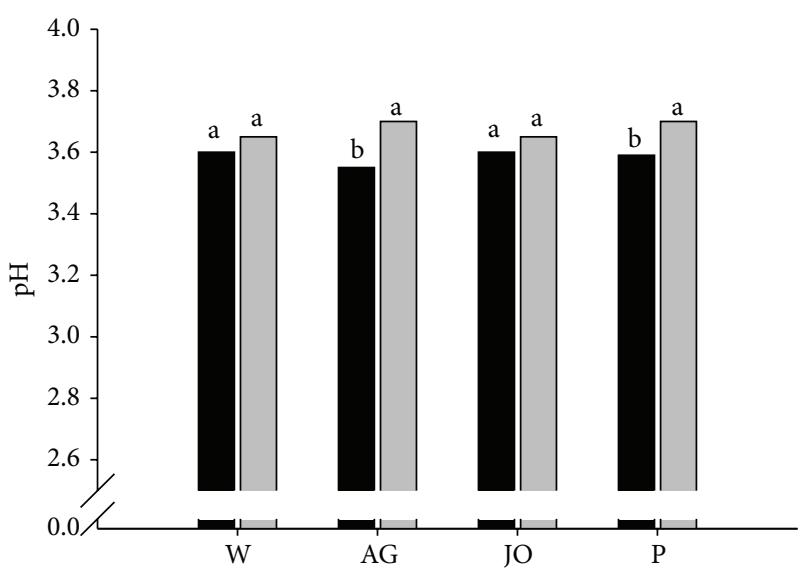

FIGURE 5: pH effect: high (black) and low (gray). Same small letters are not significantly different from each other $(P>0.05)$.

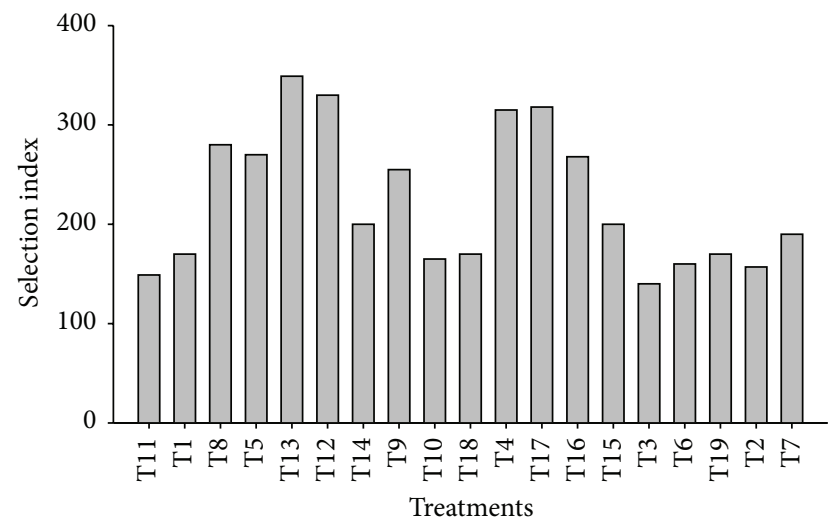

FIGURE 6: Selection index.

3.1.5. $\mathrm{pH}$ Values. The $\mathrm{pH}$ values (Figure 5) show no significant difference when using higher or lower concentration of candelilla wax and jojoba oil; nevertheless, when higher concentration of gum arabic and $\mathrm{PPH}$ is used, $\mathrm{pH}$ values increased. This change in $\mathrm{pH}$ was significantly low in comparison with the negative control samples, while the best results were obtained with T13 $(P<0.05)$. These results are consistent with those obtained by Gonzales-Aguilar et al. [14] that found a decrease in the increase of $\mathrm{pH}$ values of papaya treated with covers. On the other hand, Cantwell and Portela [40] observed an increase in the $\mathrm{pH}$ of melon stored at $5^{\circ} \mathrm{C}$ and Saucedo-Pompa et al. [9] found a decrease in $\mathrm{pH}$ increasing in avocado treated with edible coatings with ellagic acid.

3.2. Sensory Evaluation. Changes in sensory attributes including odor, flavor, and texture of coated and uncoated fruits were taste at the end of shelf life assay. Sensory evaluation was performed only to those treatments with values above 270 in the selection index. The results indicate no significant difference $(P<0.05)$ among sensory attributes of the 7 treatments, and it is remarkable that the presence of the coating does not change these sensory attributes.
Nevertheless, significant difference $(P<0.05)$ was found in the attribute of appearance of commercial treatment with respect to the other ones $(4,5,8,9,12$, and 13$)$. There is no significant difference between treatments $(P=0.01)$ on sensory attributes of appearance and taste.

Bárcenas et al. [41] indicate that, at the time of evaluating the preference of a product, consumers do not have the same concepts of quality, which makes an extensive margin of preference; this means that each consumer can get a sense of what is the smell, taste, texture, and appearance as considered ideal. Organoleptic preferences for many foods are influenced by regional culture [42] and it is necessary to determine, for each product, the standards that meet the target market [43]. Similar results were obtained by Zhou et al. [29] and Oms-Oliu et al. [28] where the use of edible coating on pears variety "Huanghua" and variety "Flor de Invierno," respectively, has no significant differences between the treatments. Also, our results of sensory evaluation are consistent with those reported by De-Leon-Zapata [44] testing taste and appearance in golden delicious apples, applying the same patented formula of edible coating based on candelilla wax and Ochoa et al. [10] carried out a triangular sensory test in golden delicious apples, applying the same patented formulation showing similar results. It means that edible coating did not modify the sensorial parameters measured.

\section{Conclusions}

The use of coating increased substantially the coating water vapor resistance that provided an attractive alternative to the fruits. In addition, the incorporation of PPH not only helped browning but also retarded the deterioration of pears. However, T13 also reduced changes in $\mathrm{pH}$, firmness, and weight loss in the fruit but the different levels of all components influenced the integrity of cell wall constituents, which affected the changes of pears. In addition, edible coatings (mainly T13) were effective in keeping sensory quality for 4 weeks.

\section{Practical Applications}

Today the main problems to be faced in the production of fruits and vegetables are their quality changes during preservation in postharvest state. Often, these products are not consumed directly from the field and take time to get to supermarkets and also to the table of consumers; besides that, in many cases these fruits and vegetables are stored and transported for long periods of time. The edible coatings are an emerging strategy to meet these demands by providing additional protection to the food acting as a selective barrier to gases and thus prolonging its shelf life. It is noteworthy that there is no universal edible coating and each formulation is specific to the food according to their characteristics.

\section{Conflict of Interests}

The authors declare that there is no conflict of interests regarding the publication of this paper. 


\section{Acknowledgment}

The authors thank CONACYT for the financial support. Author Virgilio Cruz thanks CONACYT for the scholarship to pursue the Program in Food Science and Technology (Universidad Autónoma de Coahuila, México).

\section{References}

[1] C. M. Oliveira, A. Alpalhão, C. Neto et al., "Efeito do 1metilciclopropeno em pera 'Rocha' em diferentes estados de maturação armazenadas em atmosfera normal," in Simpósio Nacional de Fruticultura, vol. 1, pp. 232-238, Actas Portuguesas de Horticultura, Alcobaça, Portugal, 2006.

[2] S. S. Ma, P. M. Chen, and E. A. Mielke, "Storage life and ripening behavior of 'Cascade' pears as influenced by harvest maturity and storage temperature," The Journal of the American Pomological Society, vol. 54, no. 3, pp. 138-147, 2000.

[3] S. Saucedo-Pompa, D. Jasso-Cantu, J. Ventura-Sobrevilla, A. Sáenz-Galindo, R. Rodríguez-Herrera, and C. N. Aguilar, "Effect of candelilla wax with natural antioxidants on the shelf life quality of fresh-cut fruits," Journal of Food Quality, vol. 30, no. 5, pp. 823-836, 2007.

[4] K. Silva de Moraes, C. Fagundes, M. C. Melo, P. Andreani, and A. R. Monteiro, "Conservation of Williams pear using edible coating with alginate and carrageenan," Ciencia e Tecnologia de Alimentos, vol. 32, no. 4, pp. 679-684, 2012.

[5] X.-H. Kou, W.-L. Guo, R.-Z. Guo, X.-Y. Li, and Z.-H. Xue, "Effects of chitosan, calcium chloride, and pullulan coating treatments on antioxidant activity in pear cv. 'Huang guan' during storage," Food and Bioprocess Technology, vol. 7, no. 3, pp. 671-681, 2014.

[6] Y. Pranoto, S. K. Rakshit, and V. M. Salokhe, "Enhancing antimicrobial activity of chitosan films by incorporating garlic oil, potassium sorbate and nisin," LWT Food Science and Technology, vol. 38, no. 8, pp. 859-865, 2005.

[7] Ç. Mecitoflu-Güçbilmez, A. Yemenicioğlu, and A. Arslanoğlu, "Antimicrobial and antioxidant activity of edible zein films incorporated with lysozyme, albumin proteins and disodium EDTA," Food Research International, vol. 40, no. 1, pp. 80-91, 2007.

[8] M. Oussalah, S. Caillet, S. Salmiéri, L. Saucier, and M. Lacroix, "Antimicrobial and antioxidant effects of milk protein-based film containing essential oils for the preservation of whole beef muscle," Journal of Agricultural and Food Chemistry, vol. 52, no. 18, pp. 5598-5605, 2004.

[9] S. Saucedo-Pompa, R. Rojas-Molina, A. F. Aguilera-Carbó et al., "Edible film based on candelilla wax to improve the shelf life and quality of avocado," Food Research International, vol. 42, no. 4, pp. 511-515, 2009.

[10] E. Ochoa, S. Saucedo-Pompa, R. Rojas-Molina, H. de la Garza, A. V. Charles-Rodríguez, and C. N. Aguilar, "Evaluation of a candelilla wax-based edible coating to prolong the shelflife quality and safety of apples," The American Journal of Agricultural and Biological Science, vol. 6, no. 1, pp. 92-98, 2011.

[11] R. Telles-Pichardo, K. Cruz-Aldaco, E. Ochoa-Reyes, C. N. Aguilar, and R. Rojas, "Edible coatings of wax and polyphenols from candelilla: an alternative of conservation of papaya (Carica papaya L.)," Acta Química Méxicana, vol. 5, no. 10, pp. 1-7, 2013.

[12] E. O. Ochoa-Reyes, G. M. Vasquez, S. S. Pompa et al., "Improvement of shelf life quality of green bell peppers using edible coating formulations," Journal of Microbiology, Biotechnology and Food Sciences, vol. 2, no. 6, pp. 2448-2451, 2013.

[13] E. Bosquez-Molina, I. Guerrero-Legarreta, and E. J. VernonCarter, "Moisture barrier properties and morphology of mesquite gum-candelilla wax based edible emulsion coatings," Food Research International, vol. 36, no. 9-10, pp. 885-893, 2003.

[14] G. A. Gonzales-Aguilar, I. N. Monroy-Garcinia, F. GoycooleaValencia, M. E. Diaz-Cinco, and J. F. Ayala-Zavala, "Covers edible chitosan. An alternative to prevent microbial spoilage and preserve quality of fresh-cut papaya," in Proceedings of the Symposium on "New Technologies for Preservation and Packaging of Fruits and Vegetables Fresh Cut Vegetables", pp. 121133, 2005.

[15] S. Saucedo-Pompa, Development of edible films from candelilla wax and antioxidants [M.S. thesis], Universidad Autónoma de Coahuila, Coahuila, México, 2007.

[16] R. Báez, E. Bringas, G. González, T. Mendoza, J. Ojeda, and J. Mercado, "Comportamiento postcosecha del mango 'Tommy Atking' tratado con agua caliente y ceras," in Proceedings of the Interamerican Society of Tropical Horticulture, vol. 44, pp. 3943, 2001.

[17] J. J. Kester and O. Fennema, "Edible films and coatings: a review," Food Technology, vol. 12, pp. 47-59, 1986.

[18] O. Assis and J. Pessoa, "Scientific note: preparation of thin films of chitosan for use as edible coatings to inhibit fungal growth on sliced fruits," Brazilian Journal of Food Science, vol. 7, pp. 17-22, 2004.

[19] C. Márquez, J. Carlos, V. Cartagena, R. Jose, Pérez-Gago, and B. Maria, "Effect of edible coatings on Japanese loquat (Eriobotrya japonica T) postharvest quality," Journal of Applied Chemistry Faculty, vol. 16, pp. 304-310, 2009.

[20] E. Bosquez-Molina, "Development of edible coatings made with mesquite gum and candelilla wax for the preservation of fruits," Food Research International, vol. 9, pp. 885-893, 2005.

[21] T. T. Hoa and M.-N. Ducamp, "Effects of different coatings on biochemical changes of 'cat Hoa loc' mangoes in storage," Postharvest Biology and Technology, vol. 48, no. 1, pp. 150-152, 2008.

[22] M. A. Islas-Osuna, N. A. Stephens-Camacho, C. A. ContrerasVergara et al., "Novel postharvest treatment reduces ascorbic acid losses in mango (Mangifera indica L.) var. Kent," American Journal of Agricultural and Biological Sciences, vol. 5, no. 3, pp. 342-349, 2010.

[23] R. D. Hagenmaier and R. A. Baker, "Reduction in gas exchange of citrus fruit by wax coatings," Journal of Agricultural and Food Chemistry, vol. 41, no. 2, pp. 283-287, 1993.

[24] ISTH, Proceedings of the Interamerican Society of Tropical Horticulture, Print Shoppe, Austin, Tex, USA, 1st edition, 1990.

[25] Ç. Özden and L. Bayindirli, "Effects of combinational use of controlled atmosphere, cold storage and edible coating applications on shelf life and quality attributes of green peppers," European Food Research and Technology, vol. 214, no. 4, pp. 320326, 2002.

[26] Ö. Yaman and L. Bayoindirli, "Effects of an edible coating and cold storage on shelf-life and quality of cherries," LWT-Food Science and Technology, vol. 35, no. 2, pp. 146-150, 2002.

[27] M. B. Perez-Gago, M. Serra, M. Alonso, M. Mateos, and M. A. Del Río, "Effect of whey protein- and hydroxypropyl methylcellulose-based edible composite coatings on color change of fresh-cut apples," Postharvest Biology and Technology, vol. 36, no. 1, pp. 77-85, 2005. 
[28] G. Oms-Oliu, R. Soliva-Fortuny, and O. Martín-Belloso, "Edible coatings with antibrowning agents to maintain sensory quality and antioxidant properties of fresh-cut pears," Postharvest Biology and Technology, vol. 50, no. 1, pp. 87-94, 2008.

[29] R. Zhou, Y. Mo, Y. Li, Y. Zhao, G. Zhang, and Y. Hu, "Quality and internal characteristics of Huanghua pears (Pyrus pyrifolia Nakai, cv. Huanghua) treated with different kinds of coatings during storage," Postharvest Biology and Technology, vol. 49, no. 1, pp. 171-179, 2008.

[30] R. Zhou, Y. Li, L. Yan, and J. Xie, "Effect of edible coatings on enzymes, cell-membrane integrity, and cell-wall constituents in relation to brittleness and firmness of Huanghua pears (Pyrus pyrifolia Nakai, cv. Huanghua) during storage," Food Chemistry, vol. 124, no. 2, pp. 569-575, 2011.

[31] Z. Xiao, Y. Luo, and Q. Wang, "Combined effects of sodium chlorite dip treatment and chitosan coatings on the quality of fresh-cut d'Anjou pears," Postharvest Biology and Technology, vol. 62, no. 3, pp. 319-326, 2011.

[32] P. Varela, A. Salvador, I. Hernando et al., "Eating quality of 'Flor de Invierno' pears: chemical and structural aspects," International Journal of Food Science and Technology, vol. 42, no. 9, pp. 1052-1058, 2007.

[33] E. L. Ghaouth, R. Ponnampalam, F. Castaigne, and J. Arul, "Chitosan coating to extend the storage life of tomatoes," HortScience, vol. 27, no. 9, pp. 1016-1018, 1992.

[34] Z. Yang, Y. Zheng, S. Cao, S. Tang, S. Ma, and N. Li, "Effects of storage temperature on textural properties of Chinese bayberry fruit," Journal of Texture Studies, vol. 38, no. 1, pp. 166-177, 2007.

[35] H. T. Lin, Y. F. Xi, and S. J. Chen, "Postharvest softening physiological mechanism of Huanghua pear fruit," Scientia Agricultura Sinica, vol. 36, pp. 349-352, 2003 (Chinese).

[36] S. Lohani, P. K. Trivedi, and P. Nath, "Changes in activities of cell wall hydrolases during ethylene-induced ripening in banana: effect of 1-MCP, ABA and IAA," Postharvest Biology and Technology, vol. 31, no. 2, pp. 119-126, 2004.

[37] M. M. Khin, W. Zhou, and S. Y. Yeo, "Mass transfer in the osmotic dehydration of coated apple cubes by using maltodextrin as the coating material and their textural properties," Journal of Food Engineering, vol. 81, no. 3, pp. 514-522, 2007.

[38] F. D. Conforti and J. B. Zinck, "Hydrocolloid-lipid coating affect on weight loss, pectin content, and textural quality of green bell peppers," Journal of Food Science, vol. 67, no. 4, pp. 1360-1363, 2002.

[39] R. Zhou, S. Su, L. P. Yan, and Y. F. Li, "Effect of transport vibration levels on mechanical damage and physiological responses of Huanghua pears (Pyrus pyrifolia Nakai, cv. Huanghua)," Postharvest Biology and Technology, vol. 46, no. 1, pp. 20-28, 2007.

[40] M. Cantwell and S. Portela, "Comparing varieties and storage method," in Fresh Cut, pp. 14-18, 1997.

[41] P. Bárcenas, R. Pérez de San Román, F. J. Pérez Elortondo, and M. Albisu, "Consumer preference structures for traditional Spanish cheeses and their relationship with sensory properties," Food Quality and Preference, vol. 12, no. 4, pp. 269-279, 2001.

[42] P. E. Witting, A. Curia, S. Calderón, L. López, R. Fuenzalida, and G. Hough, "A cross-cultural study of strawberry yogurt smoothie: consumer acceptability versus trained sensory quality panels," American Archives of Nutrition, vol. 55, pp. 77-85, 2005.

[43] F. J. Pérez-Elortondo, M. Ojeda, M. Albisu, J. Salmerón, I. Etayo, and M. Molina, "Food quality certification: an approach for the development of accredited sensory evaluation methods," Food Quality and Preference, vol. 18, no. 2, pp. 425-439, 2007.

[44] M. De Leon-Zapata, Formulation and implementation of a coverbased edible candelilla wax with the addition of an aqueous extract of Flourensia cernua [M.S. thesis], University Autónoma de Coahuila, Saltillo, Mexico, 2010. 

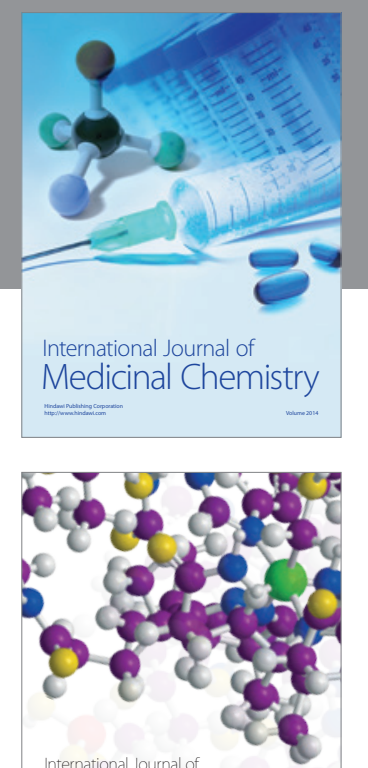

\section{Carbohydrate} Chemistry

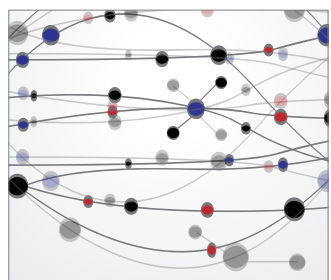

The Scientific World Journal
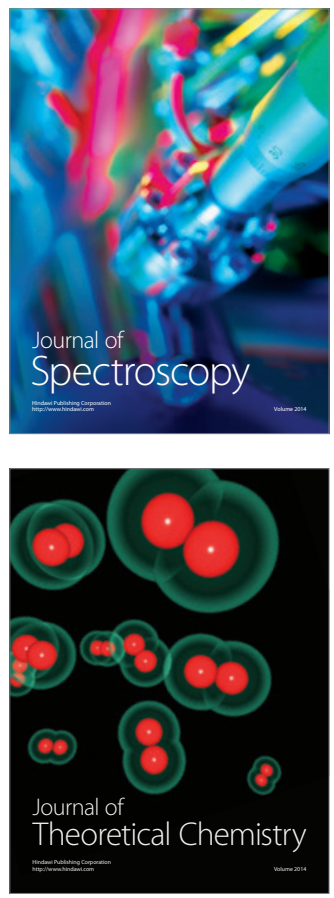
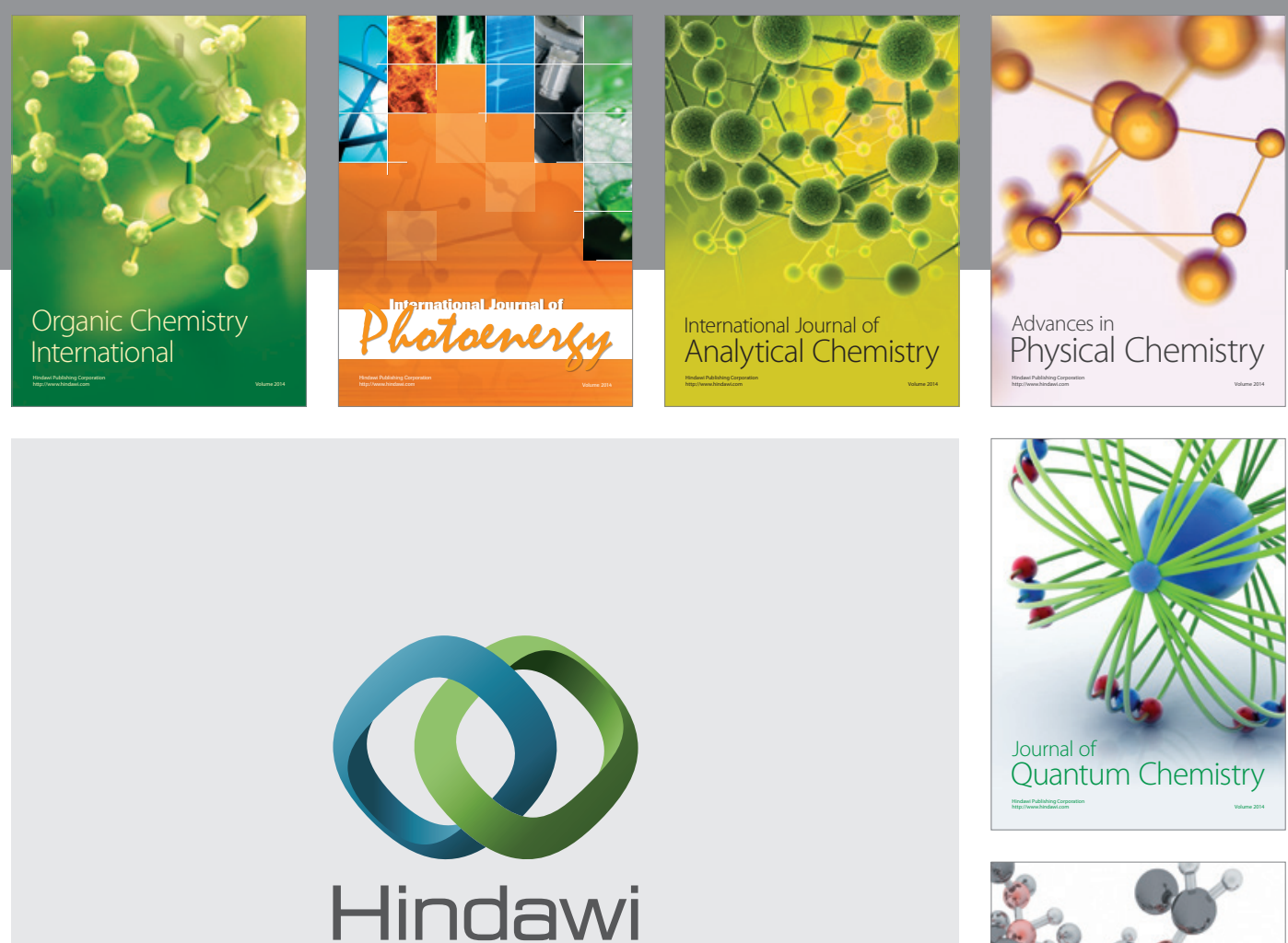

Submit your manuscripts at

http://www.hindawi.com

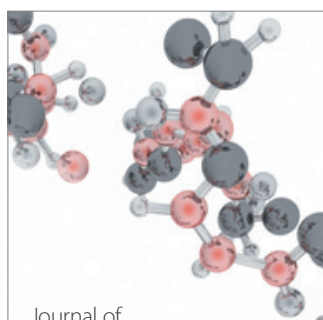

Analytical Methods

in Chemistry

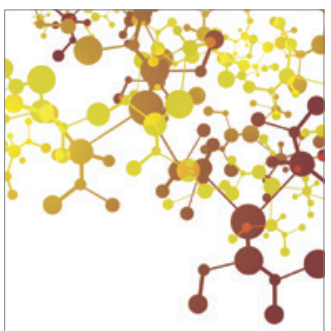

Journal of

Applied Chemistry

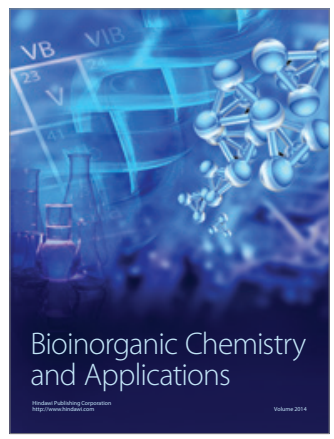

Inorganic Chemistry
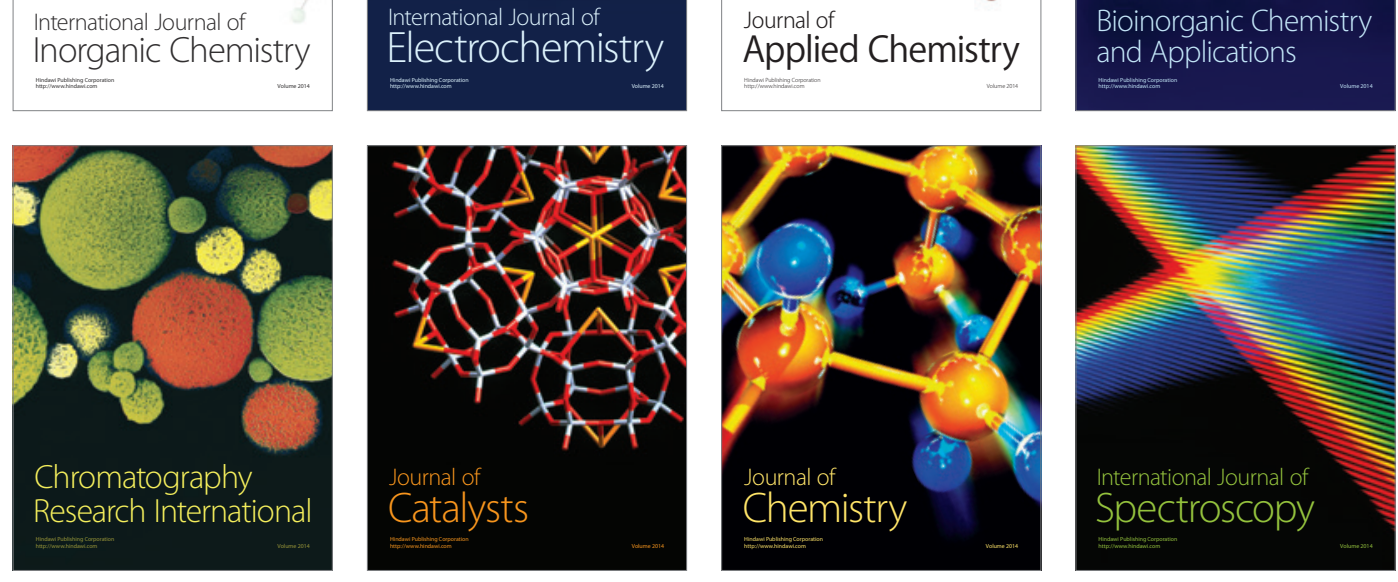